\section{A Comparison of Turfgrass Response to Biologically Amended Fertilizers}

\author{
Charles H. Peacock ${ }^{1}$ and Paul F. Daniel ${ }^{2}$ \\ Department of Crop Science, North Carolina State University, Raleigh, \\ NC 27695
}

\begin{abstract}
Additional index words. bermudagrass, Cynodon sp., Festuca arundinacea, inoculant, natural organics, nitrogen uptake, Rhizoctonia infection, tall fescue
\end{abstract}

\begin{abstract}
Initial release of $\mathbf{N}$ from waste materials used as natural organic $\mathbf{N}$ carriers for turfgrass may be slow due to the need for microbial degradation. In a greenhouse study, 'Rebel' tall fescue (Festucau arundinacea Schreb.) and 'Tifway' bermudagrass [Cynodon dactylon (L.) Pers. $\mathrm{x} C$. transvaalensis Burtt-Davy] growth response to a natural organic fertilizer (Turf Restore) amended or not amended with a soil-derived microbiological inoculum were compared with soluble urea using sterilized and nonsterilized soil. No interactions of soil sterilization and fertilizers were noted at 19 days after treatment (DAT). Urea fertilizer increased tall fescue growth rates by $68 \%$ in the nonsterilized soil and $\mathbf{1 2 6 \%}$ in the sterilized soil compared to rates for turf grown with inoculated Turf Restore. Nitrogen uptake rate was $419 \%$ higher with urea-fertilized turf in the sterilized soil than for turf fertilized with inoculated Turf Restore. Soil sterilization at 33 DAT no longer affected turf response, but turf growth rate was $133 \%$ higher and $\mathrm{N}$ uptake $353 \%$ higher with urea fertilization than with inoculated Turf Restore. Infection of the plants with Rhizoctonia spp. at 72 DAT was unaffected by fertilizer treatments. Bermudagrass response was similar to that of tall fescue. Growth rate was $67 \%$ and $N$ uptake $51 \%$ higher with urea than with Turf Restore through 17 DAT, regardless of inoculant addition. Amendment of the natural organic fertilizer Turf Restore with a soil-derived biological inoculant did not enhance turf growth rate or $\mathbf{N}$ uptake nor impact infection with Rhizoctonia spp.
\end{abstract}

Natural organic fertilizers are materials of plant and animal origin that require microbial activity for $\mathrm{N}$ release. Before 1850 , almost all fertilizers were of natural origin. Since the 1960s, there has been a shift to the use of synthetic $\mathrm{N}$ fertilizers (Tisdale and Nelson, 1975). Processed organic wastes, such as activated sewage sludges, account for only $\approx 0.1 \%$ of the fertilizer $\mathrm{N}$ consumed in the United States, even though they represent the largest total tonnage of slow-release $\mathrm{N}$ fertilizers (Hauck, 1985). There is renewed interest in expanding the use of natural organic materials as turf fertilizers in response to the need to find alternatives to landfill dumping. Release of $\mathrm{N}$ from natural organic materials at a rate that is of practical benefit to turfgrasses depends on degradation by soil microorganisms. Turf response can be significantly reduced compared with other $\mathrm{N}$ sources depending on environmental conditions (Volk and Horn, 1975). Amending natural organic fertilizers with an inoculum of soil-derived microorganisms and enzymes

Received for publication 24 Oct. 1991. Accepted for publication 8 May 1992. Mention of a trade name, proprietary product, or vendor does not constitute a guarantee or warranty of the product by North Carolina State Univ. and does not imply its approval to the exclusion of other products or vendors that also may be suitable. The cost of publishing this paper was defrayed in part by the payment of page charges. Under postal regulations, this paper therefore must be hereby marked advertisement solely to indicate this fact. should be addressed.

${ }^{2}$ Graduate Assistant.
${ }^{1}$ Associate Professor, to whom reprint requests may hasten $\mathrm{N}$ release and improve initial turfgrass response. Berndt (1986) found acceptable Kentucky bluegrass (Poa pratensis L.) performance in field trials using amended natural organic fertilizer materials. However, he concluded that while natural organic materials compared favorably with other slowrelease $\mathrm{N}$ carriers, the turf did not respond as quickly as when fertilized with soluble urea. Our study compared turfgrass growth and $\mathrm{N}$ uptake under greenhouse conditions following applications of 1) natural organic fertilizer that was microbiologically amended, 2) an identical nonamended material, and 3) urea. Comparisons were made using sterilized and nonsterilized soil.

Separate greenhouse studies were conducted in 1990 at North Carolina State Univ., Raleigh, to evaluate the response of 'Rebel' tall fescue and 'Tifway' bermudagrass to Turf Restore (Ringer Corp., Minneapolis), a natural organic fertilizer. The greenhouse was

Table 1. Analysis of variance for tall fescue and bermudagrass growth rate, $\mathrm{N}$ uptake, and disease incidence as affected by fertilizer and soil sterilization.

\begin{tabular}{lccccc}
\hline \hline \multirow{2}{*}{$\begin{array}{l}\text { Turf and } \\
\text { treatment }\end{array}$} & \multicolumn{5}{c}{ Days after treatment } \\
\cline { 2 - 6 } & 19 & 33 & 19 & 33 & 72 \\
\hline Tall fescue & & & & & \\
Fertilizer & $\quad * * *$ & $* * *$ & $* * *$ & $* *$ & NS \\
$\quad$ treatments (FT) & $* * *$ & NS & $* *$ & NS & $* * *$ \\
Soil sterilization (SS) & NS & NS & NS & NS & NS \\
FT $\times$ SS & 17 & 31 & 17 & 31 & \\
Bermudagrass & $* * *$ & NS & $* * *$ & NS & $\ldots$ \\
FT & NS & NS & NS & NS & $\ldots$ \\
SS & NS & NS & NS & NS & $\ldots$ \\
FT $\times$ SS &
\end{tabular}

${ }^{\mathrm{ss}}, * *, * * *$ Nonsignificant or significant at $P=0.01$ or 0.001 , respectively. hand watering. We used a completely randomized design with four replications.

Tall fescue was seeded at $40 \mathrm{~g} \cdot \mathrm{m}^{-2}$ and seedlings were allowed to establish for 2 weeks before fertilizer application. At that time, grass in the pots was uniformly clipped to a 50-mm height. Topgrowth above the 50mm clipping height was harvested at 19 and 33 days after fertilizer treatment (DAT). Clippings were dried at $75 \mathrm{C}$ for $24 \mathrm{~h}$ and weighed. Growth rate was determined as a daily average for the entire period between harvests based on dry weight and number of days of regrowth since last clipping. Tissue samples were ground (Udy Cyclone Sample Mill Model 3010; Udy Corp., Ft. Collins, Colo.) to pass a $0.5-\mathrm{mm}$ screen, and a 10 $\mathrm{mg}$ sample was analyzed for $\mathrm{N}$ content (Perkin Elmer 2400 CHN Elemental Analyzer; Perkin Elmer Corp., Norwalk, Conn.). Disease incidence of Rhizoctonia spp. at 72 DAT maintained at 18 to $29 \mathrm{C}$ and under natural daylengths. Studies were conducted during March and April for tall fescue and July and August for bermudagrass. Duplicate samples of Turf Restore were provided that were $(+)$ or were not (-) microbiologically amended with a soil-derived inoculum. The exact composition of the inoculum is confidential, but it contains bacteria including Bacillus subtilis and other Bacillus sp., fungi related to Trichoderma viride, actinomycetes, and enzymes with $\approx 1.5 \times 10^{6}$ total organisms per gram of material. Turf Restore is a $10 \mathrm{~N}$ 0.9P-5.0K fertilizer derived from feather meal, soybean meal, blood meal, bone meal, and $\mathrm{K}_{2} \mathrm{SO}_{4}$. As a comparison, a third treatment consisted of an identical fertilizer ratio prepared from a mixture of urea $(45 \mathrm{~N}-0 \mathrm{P}-$ $0 \mathrm{~K})$, triple superphosphate $(0 \mathrm{~N}-20 \mathrm{P}-\mathrm{K})$, and $\mathrm{K}_{2} \mathrm{SO}_{4}(0 \mathrm{~N}-0 \mathrm{P}-41 \mathrm{~K})$.

Grasses were established in the greenhouse in $15-\mathrm{cm}$ diameter plastic pots with a total volume of $2800 \mathrm{~cm}^{3}$. Pots were sterilized with a $0.0025 \%$ sodium hypochlorite solution. A soil mix was used that consisted of $70 \%$ medium sand : $20 \%$ sphagnum peatmoss : $10 \%$ sandy loam soil (by volume). Half of the soil mixture was steam sterilized at $79 \mathrm{C}$ for $2 \mathrm{~h}$ to reduce initial competition from naturally occurring soil microbes with the inoculum. About $1700 \mathrm{~g}$ of soil was placed in each pot. Fertilizers were applied as a single application at $5 \mathrm{~g} \mathrm{~N} / \mathrm{m}^{2}$. Irrigation was provided at $12 \mathrm{~mm}$ three times per week by

HortScience, Vol. 27(8), August 1992 
Table 2. Growth rate and $\mathrm{N}$ uptake of tall fescue between 0 and 19 days after treatment in response to soil sterilization and fertilizer treatment.

\begin{tabular}{|c|c|c|c|c|}
\hline \multirow[b]{2}{*}{ Fertilizer $^{2}$} & \multicolumn{2}{|c|}{$\begin{array}{c}\text { Growth rate } \\
\left(\mathrm{mg} \cdot \mathrm{m}^{-2}\right. \\
\left.\cdot \text { day }^{-1}\right)\end{array}$} & \multicolumn{2}{|c|}{$\begin{array}{l}\mathrm{N} \text { uptake } \\
\text { (mg N/m } / \mathrm{m}^{2} \\
\text { per day) }\end{array}$} \\
\hline & Sterile $^{y}$ & $\begin{array}{c}\text { Non- } \\
\text { steriley }^{y}\end{array}$ & Sterile ${ }^{y}$ & $\begin{array}{l}\text { Non- } \\
\text { sterile }\end{array}$ \\
\hline $\begin{array}{l}\text { Turf } \\
\text { Restore }+ \\
\text { Turf }\end{array}$ & $381 b^{x}$ & $795 \mathrm{~b}$ & $7.3 \mathrm{~b}$ & $23.4 \mathrm{~b}$ \\
\hline $\begin{array}{l}\text { Restore - } \\
\text { Urea } \\
\text { (not amended) }\end{array}$ & $337 \mathrm{~b}$ & $505 \mathrm{~b}$ & $\begin{array}{r}9.9 \mathrm{~b} \\
37.9 \mathrm{a}\end{array}$ & $11.7 \mathrm{~b}$ \\
\hline
\end{tabular}

${ }^{2}$ Turf Restore biologically amended (+) or not amended with (-) microbes.

'Soil treatment.

${ }^{x}$ Mean separation in columns by the Waller-Duncan $\mathrm{k}$-ratio $\mathrm{t}$ test $(\mathrm{k}$ ratio $=100)$.

Table 3. Growth rate and $\mathrm{N}$ uptake of tall fescue at 33 days after treatment as affected by fertilizer treatment.

\begin{tabular}{|c|c|c|}
\hline Fertilizer $^{2}$ & $\begin{array}{c}\text { Growth } \\
\text { rate } \\
\left(\mathrm{mg}^{-2} \mathrm{~m}^{-2} \text { day }{ }^{-1}\right)\end{array}$ & $\begin{array}{c}\mathrm{N} \text { uptake } \\
\left(\mathrm{mg} \mathrm{N} / \mathrm{m}^{2}\right. \\
\text { per day) }\end{array}$ \\
\hline Turf & & \\
\hline $\begin{array}{l}\text { Restore + } \\
\text { Turf }\end{array}$ & $296 b^{y}$ & $5.7 \mathrm{~b}$ \\
\hline Restore - & $312 \mathrm{~b}$ & $8.8 \mathrm{~b}$ \\
\hline $\begin{array}{l}\text { Urea } \\
\text { (not amended) }\end{array}$ & $690 \mathrm{a}$ & $25.8 \mathrm{a}$ \\
\hline
\end{tabular}

${ }^{2}$ Turf Restore biologically amended (+) or not amended (-) with microbes.

'Mean separation in columns by the Waller-Duncan $\mathrm{k}$-ratio $\mathrm{t}$ test $(\mathrm{k}$ ratio $=100)$.

Table 4. Growth rate and $\mathrm{N}$ uptake of bermudagrass at 17 days after treatment as affected by fertilizer treatment.

\begin{tabular}{lcc}
\hline \hline & $\begin{array}{c}\text { Growth } \\
\text { rate } \\
\left(\mathrm{mg}^{-2} \cdot \mathrm{day}^{-1}\right)\end{array}$ & $\begin{array}{c}\mathrm{N} \text { uptake } \\
\left(\mathrm{mg} \mathrm{N} / \mathrm{m}^{2}\right. \\
\text { per day) }\end{array}$ \\
\hline $\begin{array}{l}\text { Fertilizer } \\
\text { Turf }\end{array}$ & $1903 \mathrm{~b}^{\mathrm{y}}$ & $70.0 \mathrm{~b}$ \\
$\begin{array}{l}\text { Restore }+ \\
\begin{array}{l}\text { Turf } \\
\text { Restore }-\end{array}\end{array}$ & $1722 \mathrm{~b}$ & $56.7 \mathrm{~b}$ \\
$\begin{array}{l}\text { Urea } \\
\text { (not amended) }\end{array}$ & $3187 \mathrm{a}$ & $105.8 \mathrm{a}$ \\
\hline
\end{tabular}

${ }^{2}$ Turf Restore biologically amended (+) or not amended (-) with microbes.

'Mean separations in columns by the Waller-Duncan k-ratio $t$ test $(\mathrm{k}$ ratio $=100)$.

where $1=100 \%$ dead and $5=100 \%$ alive shoot tissue. Samples of infected tissue were submitted to the North Carolina State Univ. Plant Disease Clinic for determination of the disease organism.

Bermudagrass was established from plugs taken from an existing turf field plot area of 'Tifway' bermudagrass. Plugs $100 \mathrm{~mm}$ in diameter were removed from a field plot and tops were uniformly trimmed for topgrowth to a $19-\mathrm{mm}$ height. The root system below the rhizomes was removed and the plug was washed to remove all soil. Plugs were established in pots filled with the soil mix previously described. Fertilizer treatments were applied immediately after planting and topgrowth above the 19-mm clipping height was harvested at 17 and 31 DAT. Tissue analysis was conducted as previously described. Data were subjected to analysis of variance (ANOVA) procedures (SAS, 1985). Mean separation when appropriate used the WallerDuncan k-ratio $t$ test with $\mathrm{k}$ ratio $=100$ (Waller and Duncan, 1969).

Fertilizer treatments influenced tall fescue growth rate and $\mathrm{N}$ uptake at 19 and 33 DAT (Table 1). Soil sterilization also affected growth rate and $\mathrm{N}$ uptake, but only at 19 DAT. Disease incidence of Rhizoctonia spp. at 72 DAT was influenced by soil sterilization, but not by fertilizer treatments. No interactions of fertilizer treatments and soil sterilization were found. At 19 DAT, tall fescue growth rates were $126 \%$ higher in the sterilized and $68 \%$ higher in the nonsterilized soil for the urea treatment than for turf grown with inoculated Turf Restore (Table 2). Nitrogen uptake rates by 19 DAT were positively related to growth rates. The relative differential was more pronounced for turf $\mathrm{N}$ uptake, which was $419 \%$ higher for the urea treatment than for turf fertilized with inoculated Turf Restore in the sterilized soil. Additionally, growth rates were $49 \%$ higher overall in nonsterilized than in sterilized soil. By 33 DAT, soil sterilization no longer affected tall fescue growth rates (Table 1). The growth rate to 33 DAT remained $133 \%$ higher with the urea treatment than with inoculated Turf Restore, and N uptake was 353\% higher (Table 3). Soil sterilization reduced turfgrass growth, presumably by a reduction in the population of soil microorganisms, which could have impacted release of $\mathrm{NH}_{4}^{+}-\mathrm{N}$ from urea and/or conversion to $\mathrm{NO}_{3}^{-}-\mathrm{N}$.

Bermudagrass response to fertilizer treatments was similar to that of tall fescue. To 17 DAT, the growth rate of the urea-treated turf was $67 \%$ higher than for turf grown with inoculated Turf Restore. Further, no differences were found between turf fertilized with amended and nonamended Turf Restore (Table 4). Bermudagrass $\mathrm{N}$ uptake was $51 \%$ higher for the urea treatment than for turf fertilized with inoculated Turf Restore. Biological amendment did not affect bermudagrass $\mathrm{N}$ uptake rates. No differences were found due to soil sterilization, probably due to natural inoculum being introduced within the thatch layer from the transplanted plugs.

Use of natural organic materials has been linked to suppression of diseases in turf (Cook et al., 1964; Markland et al., 1969). However, Markland et al. (1969) could not correlate the use of sewage sludge or processed tankage and an increase in soil microbial activity with suppression of dollar spot (Sclerotinia homoeocarpa F.T. Bennett) on creeping bentgrass (Agrostis palustris Huds). Based on disease incidence of Rhizoctonia spp. of tall fescue in this experiment, fertilizer treatment had no effect on preventing disease incidence (Table 1). There was a significant reduction of incidence of Rhizoctonia infection of the tall fescue on sterilized (rating of $3.6 ; 1=$ dead and $5=$ alive) compared with nonsterilized (rating of 2.4) soil. This difference is probably related to suppression of disease activity from natural pathogen populations present in the soil that were eliminated or greatly reduced by soil sterilization. Apparently, the use of a natural organic fertilizer that had been microbiologically amended did not afford an advantage in disease suppression in this study, even with sterilized soil.

Turf Restore that had been biologically amended $(+)$ did not provide for faster fertilizer availability, based on turf growth rates and $\mathrm{N}$ uptake rates, than nonamended material (-). Use of a Pseudomonas sp. inoculant to enhance organic $\mathrm{N}$ carrier degradation in the field was not effective on bermudagrass (Peacock and DiPaola, 1992). In this study, even under sterilized soil conditions, where naturally occurring soil microorganism populations presumably were eliminated or greatly reduced, the biologically amended fertilizer did not lead to an increased $\mathrm{N}$ release rate based on measurements of turfgrass growth or $\mathrm{N}$ uptake. Thus, the addition of soil microorganisms as a biological amendment to a natural organic fertilizer was not beneficial in this study.

\section{Literature Cited}

Berndt, W.L. 1986. Turfgrass response to bioorganic amendments. MS Thesis, Michigan State Univ., East Lansing.

Cook, R.N., R.E. Engel, and S. Bachelder. 1964. A study of the effect of nitrogen carriers on turfgrass disease. Plant Dis. Rptr. 48:254-255.

Hauck, R.D. 1985. Slow-release bioinhibitoramended nitrogen fertilizers. p. 293-322. In: O.P. Englestad (ed.). Fertilizer technology and use. Soil Sci. Soc. Amer. Madison, Wis.

Markland, F.E., E.C. Roberts, and L.R. Frederick. 1969. Influence of nitrogen fertilizers on Washington creeping bentgrass, Agrostis palustris Huds. II. Incidence of dollar snot. Sclerotinia homoeocarpa, infection. Agron. J. 61:701-705.

Peacock, C.H. and. J.M. DiPaola. 1992. Turf response to triazine carriers as influenced by Pseudomonas inoculant. Agron. J. 84:583-585.

SAS Institute. 1985. SAS/STAT guide for personal computers, version 6 (ed.). SAS Institute, Gary, N.C.

Tisdale, S.L. and W.L. Nelson. 1975. Soil fertility and fertilizers MacMillan, New York.

Volk, G.M. and G.C. Horn. 1975. Response curves of various turfgrasses to application of several controlled release nitrogen carriers. Agron. J. 67:201-204.

Waller, R.A. and D.B. Duncan. 1969. A Bayes rule for the symmetric multiple comparisons problem. J. Amer. Stat. Assn. 64:1484-1503. 